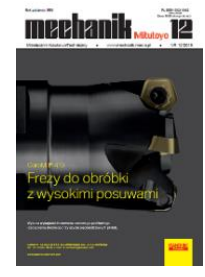

How to cite this article:

Authors: Piotr Szablewski, Tadeusz Chwalczuk, Tomasz Dobrowolski

Title of article: „, Evaluation of the cutting insert condition influence on the microstructure of surface layer after turning of Inconel 718 alloy"

Mechanik, No. 12 (2019)

DOI: https://doi.org/10.17814/mechanik.2019.12.111

\title{
Evaluation of the cutting insert condition influence on the microstructure of surface layer after turning of Inconel 718 alloy
}

\author{
PIOTR SZABLEWSKI \\ TADEUSZ CHWALCZUK \\ TOMASZ DOBROWOLSKI *
}

Dr inż. Piotr Szablewski, piotr.szablewski@pwk.com.pl, https://orcid.org/0000-0003-2435-2126 - Pratt \& Whitney Kalisz, Polska,

Państwowa Wyższa Szkoła Zawodowa, Kalisz, Polska

Mgr inż. Tadeusz Chwalczuk, tadeusz.chwalczuk@put.poznan.pl, https://orcid.org/0000-0002-4009-0552 - Politechnika Poznańska, Poznań, Polska

Mgr inż. Tomasz Dobrowolski, tomasz.dobrowolski@pwk.com.pl - Pratt \& Whitney Kalisz, Polska

Research concerns the evaluation of the cutting insert condition on the microstructure of the surface layer after longitudinal turning of Inconel 718 alloy using carbide inserts. Value of the $V_{B} B_{C}$ wear index after dry machining with variable feed $f$ and depth of cut $a_{p}$ was evaluated. White layer was observed up to $2,5 \mu \mathrm{m}$.

KEYWORDS: Inconel 718, white layer, inserts wear

\section{Introduction}

Heat resistant alloys - such as Inconel or Waspaloy - are widely used in aircraft engine constructions. Unfortunately, the properties, due to which they are used so widely, also hamper their mechanical machining $[1,2]$. Poor machinability of these alloys is manifested, among others, by short durability of cutting blades, which directly translates into the quality of the surface layer (roughness of the treated surface, microstructure) [3].

The notion of a white layer (WL) occupies a special place in the assessment of the surface condition of Inconel 718 alloy. Due to its properties, WL is often a critical element of technological surface layer (TSL), which affects the operational properties of critical parts of the structure.

White layer formed in the machining process of the Inconel 718 alloy after precipitation hardening is primarily nanocrystalline grains with a size of $50 \div 100 \mathrm{~nm}$ [4], the size of which before machining was about 23 $\mu \mathrm{m}$. Areas of surface unevenness with numerous dislocations with grains of approximately $200 \mathrm{~nm}$ can also be observed. In the white layer, there is mainly the strengthened phase $\gamma$, phase $\gamma^{\prime} \mathrm{Ni}_{3}(\mathrm{Al}, \mathrm{Ti})$ and $\delta$ of the $\mathrm{Ni}_{3} \mathrm{Nb}$ type [4].

Mechanism of the formation of a white layer in the cutting process is associated with the appearance of high temperatures, plastic deformation of the machined layer and chemical reactions [5], which is undoubtedly due to the state of the blade edge. Furthermore, carrying out machining with a worn tool causes significant stresses in the surface layer (SL) [6, 7].

It has been shown that during conventional turning of the Inconel 718 alloy, tensile stresses are observed at the surface of the machined material, followed by - to a certain depth - compressive stresses. Values of these stresses depend on the cutting parameters and geometry of the blade, and above all - on the value of the rounding radius $r n$.

The authors of the article [8] showed that the use of coolant reduces the depth of occurrence of SL stress changes compared to dry machining. During the finishing turning of the Inconel 718 alloy, it was observed that the depth of the blade impact on the stress values may differ by $0.15 \mathrm{~mm}$ in the cutting speed range $v_{c}=40 \div 80$ $\mathrm{m} / \mathrm{min}$. This effect is associated with less deformation of the machined layer. 
For many grades of Inconel 718 alloy, formation of a white layer during machining is inevitable. Direction of a modern research and issue for optimization should be the selection of cutting parameters and conditions to obtain a white layer of assumed thickness and known character. The state of the art regarding the formation of this characteristic zone in nickel-based alloys is insufficient. This is especially true for turning Inconel 718 after various heat treatments.

\section{Scope, conditions and technique of research}

The tests concerned longitudinal turning of an Inconel 718 shaft in the supersaturated state with a hardness of 20 HRC. The state of the core microstructure is shown in fig. 1.

WNMG 080408-PP multi-edge inserts with corner radius $r_{\varepsilon}=0.8 \mathrm{~mm}$ and TiCN/TiN coating (applied by PVD method), DWLNR $2525 \mathrm{M} 08$ holder and main entering angle $\kappa_{r}=95^{\circ}$ were used. Turning tests were carried out on a universal TUR560 lathe; no cooling lubricant was used.

Photographs of the microstructures were taken with an EPIPHOT 200 microscope from Nikon. Samples were incorporated in duracryl and digested with Kallings reagent after polishing.

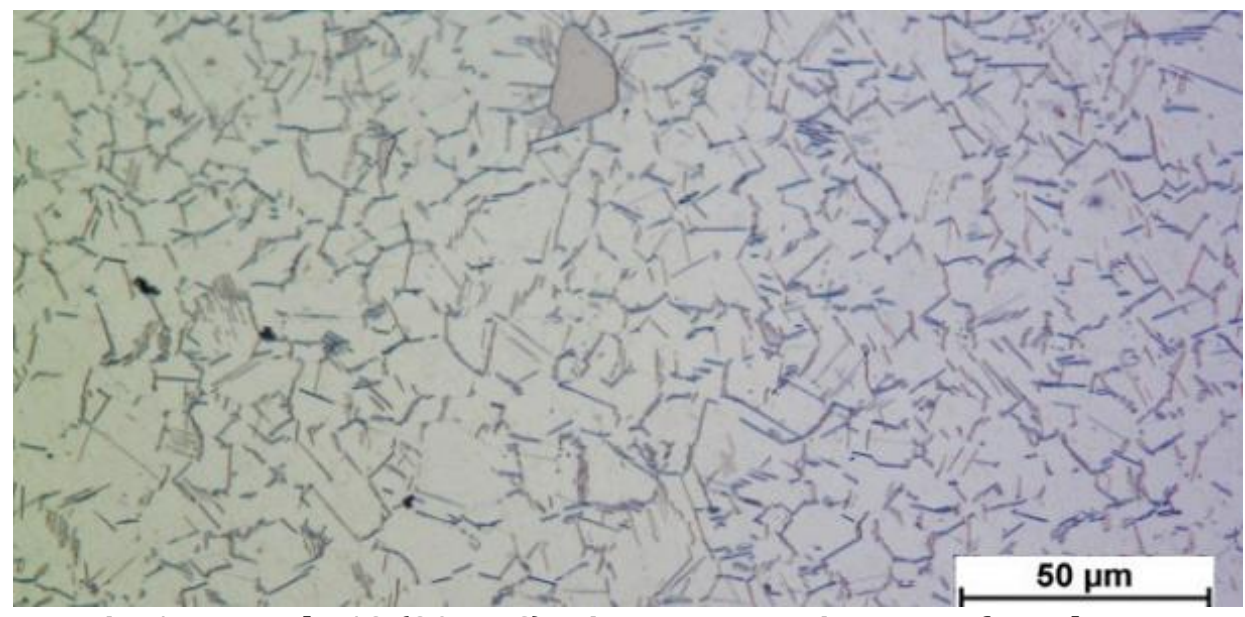

Fig. 1. Inconel 718 (20 HRC) microstructure in a transferred state

Surface roughness was recorded on a Hommel Tester T1000 profilograph. Roughness parameters $R a$ and $R z$ were measured according to DIN, over the measuring section $L t=4.80 \mathrm{~mm}$.

\section{Analysis of test results}

Figs. 2-6 show the microstructure of Inconel 718 with a hardness of $20 \mathrm{HRC}$ after turning with a new blade and blades with a wear of $V B_{C}=0.12 \mathrm{~mm}$ and $0.25 \mathrm{~mm}$. In each of the analyzed cases, an austenitic alloy microstructure with clearly defined grain boundaries can be observed.

A characteristic feature of the Inconel 718 alloy is the presence of hard niobium and titanium carbides in the structure. This clearly affects the quality of the machined surface [9]. In fig. 2, after turning with a new blade, one can see clear gaps related to the kinematic and geometrical nature of the blade mapping in the material. In fig. 3, after turning with a worn blade $\left(V B_{C}=0.12 \mathrm{~mm}\right)$, the intervals between the blade passes disappear. There are material losses on the machined surface due to the phenomenon of adhesion between the blade and the chip as well as the effect of lateral flow of the material. 


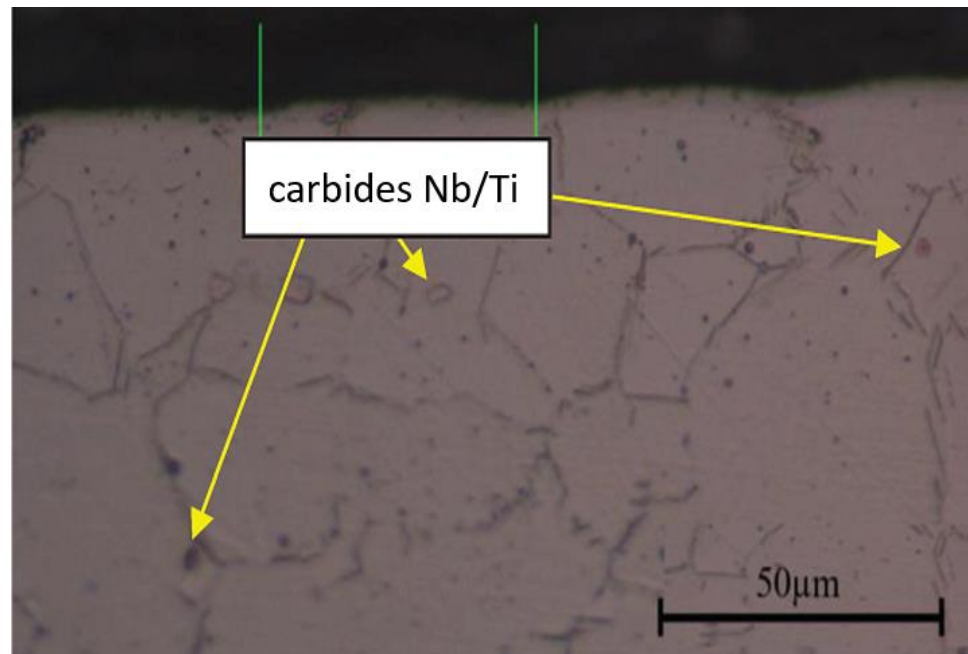

Fig. 2. Inconel 718 (20 HRC) microstructure after turning with WNMG 080408-TF IC3028; $v_{c}=40 \mathrm{~m} / \mathrm{min}, f=0.05 \mathrm{~mm} / \mathrm{rev}, a_{p}=0.20 \mathrm{~mm}, V B_{C}=0 \mathrm{~mm}$

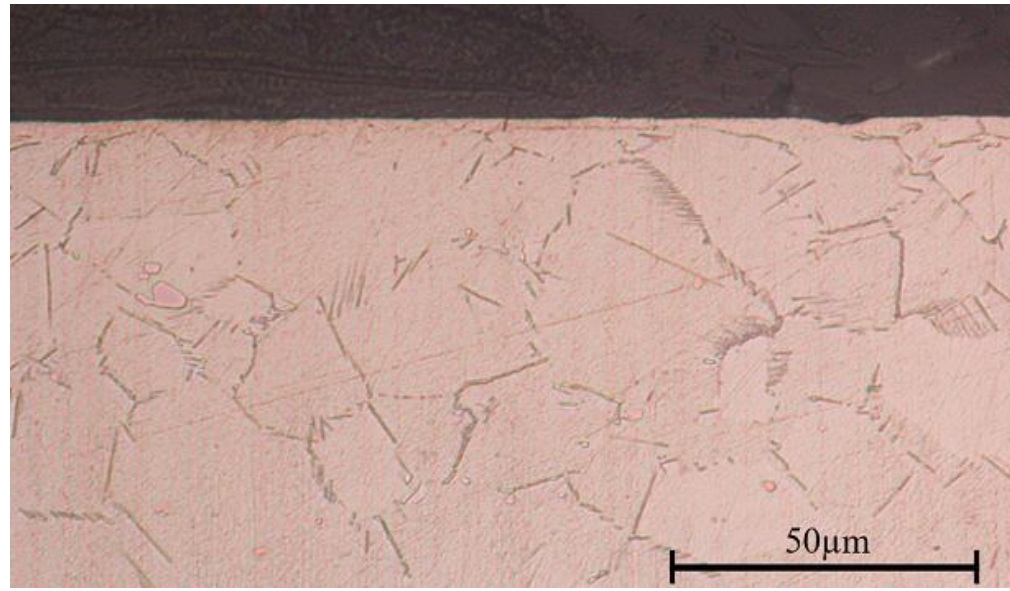

Fig. 3. Inconel 718 (20 HRC) microstructure after turning with WNMG 080408-TF IC3028; $v_{c}=40 \mathrm{~m} / \mathrm{min}, f=0.05 \mathrm{~mm} / \mathrm{rev}, a_{p}=0.20 \mathrm{~mm}, V B_{C}=0.12 \mathrm{~mm}$

Even greater changes on the machined surface occur after cutting with a worn insert with $V B_{C}=0.25 \mathrm{~mm}$ (figs. 4 and 5). Presented microstructure shows the raw material in the form of strips arranged according to the direction of feed. On the other hand, fig. 6 shows a microcrack and a very thin (approximately $1.5 \mu \mathrm{m}$ ) WL, mentioned by the authors of the work [10]. This layer is a load in the presented research. It is not associated with the presence of additional chemical agents that may affect the microstructure of WW. Based on the analysis of figs. $2-5$, it can be clearly stated that the occurrence of WL is primarily associated with the state of the cutting edge. As a result of the progressive wear of the cutting edge, it is impossible to avoid its generation, while the technological goal should be to avoid discontinuities manifested in machined surface anomalies.

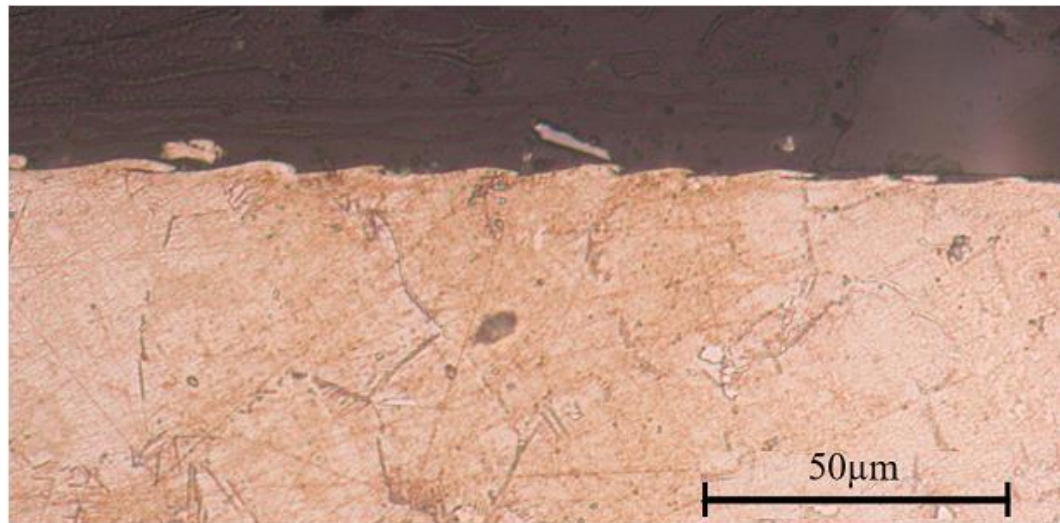

Fig. 4. Microstructure of Inconel 718 (20 HRC) after turning with WNMG 080408-TF IC3028; $v_{c}=40 \mathrm{~m} / \mathrm{min}, f=0.05 \mathrm{~mm} / \mathrm{rev}, a_{p}=0.20 \mathrm{~mm}, V B_{C}=0.25 \mathrm{~mm}$ 


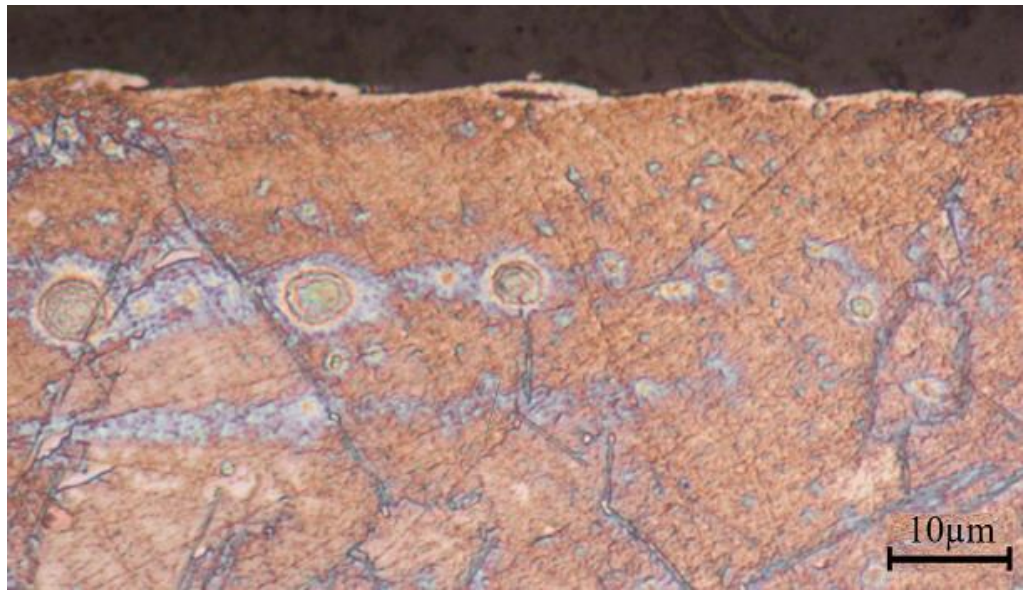

Fig. 5. Inconel 718 (20 HRC) microstructure after turning with WNMG 080408-TF IC3028; $v_{c}=40 \mathrm{~m} / \mathrm{min}, f=0.05 \mathrm{~mm} / \mathrm{rev}, a_{p}=0.20 \mathrm{~mm}, V B_{C}=0.25 \mathrm{~mm}$

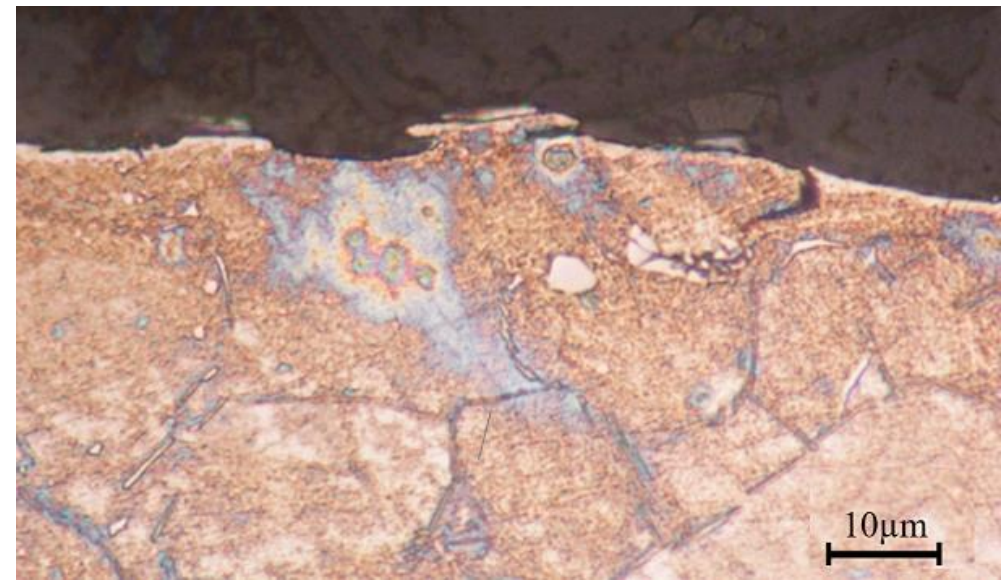

Fig. 6. Inconel 718 (20 HRC) microstructure after turning with WNMG 080408-TF IC3028; $v_{c}=40 \mathrm{~m} / \mathrm{min}, f=0.05 \mathrm{~mm} / \mathrm{rev}, a_{p}=0.20 \mathrm{~mm}, V B_{C}=0.25 \mathrm{~mm}$ (visible microcracking)

Under the WL, the deformation zone of austenite grains can be seen. This is a typical image associated with the load resulting from the contact of blade with material. This deformation strengthens TSL. The increase in surface hardness is an important factor affecting the machinability of the Inconel 718 alloy. The effect of strengthening the TSL has been described in detail, among others in works $[3,8]$.

Values of roughness parameters for individual blade states are summarized in the table, while in fig. 7, the roughness profiles for subsequent transitions are collected. Progressive wear of the blade did not contribute to the increase in the value of $R a$ and $R z$ roughness parameters. This effect can be explained by the phenomenon of plasticizing and indenting of uncut material (resulting from the appearance of build-up and lateral flow of the chip). This may be the result of TSL discontinuities described previously.

TABLE. Roughness parameters of the machined surface of the Inconel 718 alloy with varying degrees of wear

\begin{tabular}{|c|c|c|}
\hline $\begin{array}{c}\text { Value of wear } \\
V B_{c}[\mathrm{~mm}]\end{array}$ & $R a[\mu \mathrm{m}]$ & $R z[\mu \mathrm{m}]$ \\
\hline 0.19 & 0.79 & 3.84 \\
\hline 0.34 & 0.64 & 3.85 \\
\hline 0.55 & 0.58 & 3.80 \\
\hline
\end{tabular}

The highest regularity of the profile shape was noted for the surface machined with a blade with the highest degree of wear analyzed. The nature of the profile for the initial blade state does not have the typical blade representation associated with longitudinal turning kinematics. This effect is not reflected in the images of the surface layer microstructure. It can be assumed that the accumulation on the machined surface was removed as a result of the preparation of metallographic specimens. 
Research on the impact of the feedrate value on the cutting edge wear during turning of Inconel 718 material confirmed that the increase in feedrate promotes the build-up of the rake surface at the cutting edge (fig. 8). The change in the contact surface of the blade with the workpiece favored the intensification of the phenomenon of adhesion. The problem of the build-up impact on the quality of the machined surface was raised, among others at work [9].

Described WW discontinuities or torn off parts of the machined surface, presented on metallographic specimens for a worn blade, are associated with stratification of individual surface zones.

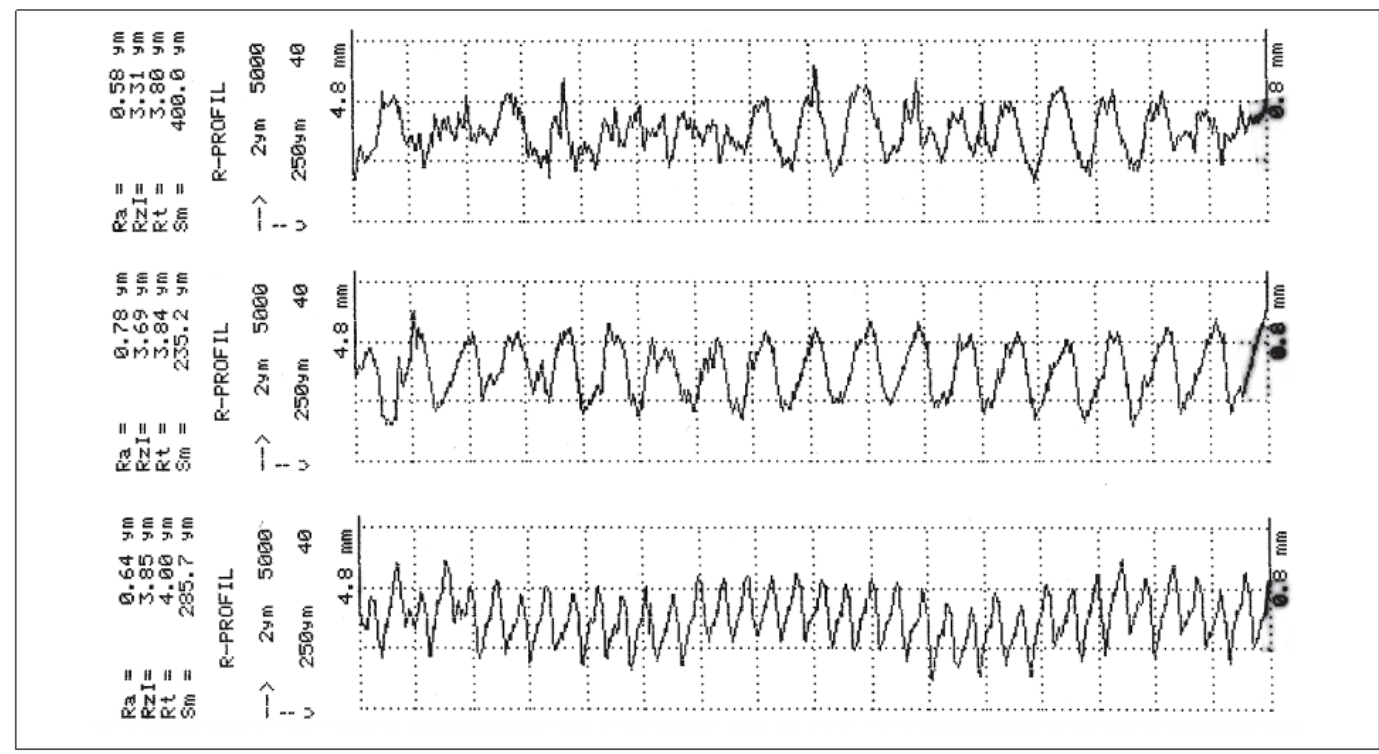

Fig. 7. Cross surface roughness profiles treated with cemented carbide IC $3028: v_{c}=60 \mathrm{~m} / \mathrm{min}, f=$ $0.105 \mathrm{~mm} / \mathrm{rev}, a_{p}=0.1 \mathrm{~mm}$; a) $V B_{C}=0.19 \mathrm{~mm}$, b) $V B_{C}=0.34 \mathrm{~mm}$, c) $V B_{C}=0.55 \mathrm{~mm}$

First of all, BW delamination from the deformed austenitic structure of the primary material was observed. The intensity of build-up on the machined surface in the initial phase of the blade operation decreases, and at the same time the share of build-up on the cutting edge increases.
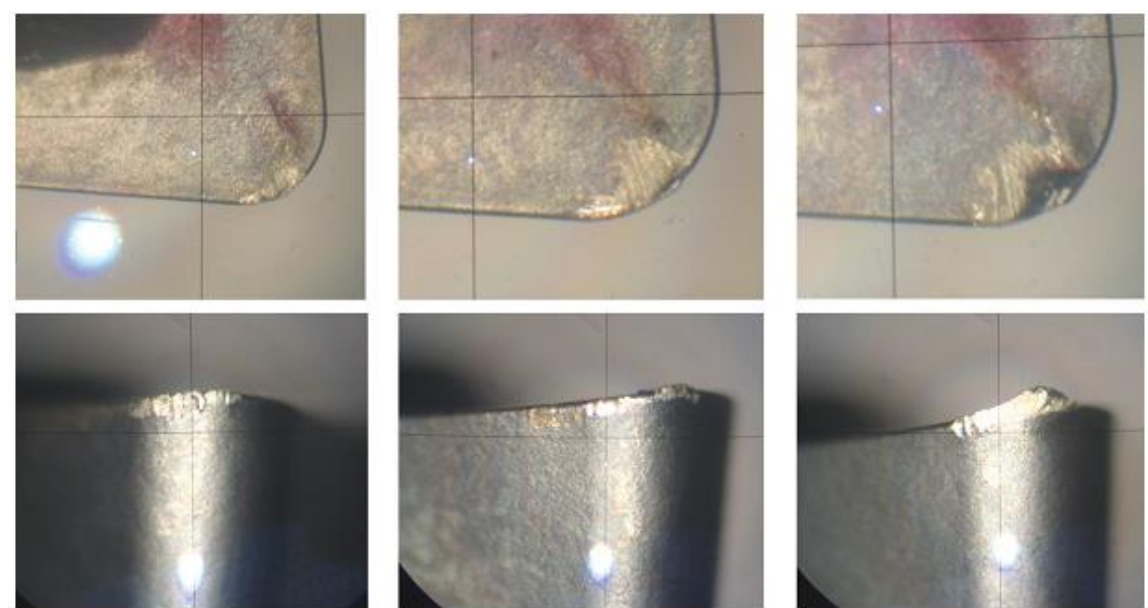

Fig. 8. IC3028 blade wear after turning Inconel $\left.718(20 \pm 2 \mathrm{HRC}): a_{p}=0.25 \mathrm{~mm}, v_{c}=60 \mathrm{~m} / \mathrm{min} ; \mathrm{a}\right) f=$ $0.05 \mathrm{~mm} / \mathrm{rev}, \mathrm{b}) f=0.105 \mathrm{~mm} / \mathrm{rev}, \mathrm{c}) f=0.21 \mathrm{~mm} / \mathrm{rev}$

\section{Summary}

When turning Inconel 718, it was noted that a build-up was formed on the cutting blades. It depends on the feedrate value - its increase causes an increase in the accumulation. The microstructures examined show dangerous phenomenon of microcracking on the machined surface with increasing wear on the flank. 


\section{REFERENCES}

[1] Leshock C.E., Kim J.N., Shin Y.C. "Plasma enhanced machining of Inconel 718: modeling of workpiece temperature with plasma heating and experimental results". International Journal of Machine Tools \& Manufacture. 41 (2001): 877-897, https://doi.org/10.1016/S0890-6955(00)00106-1.

[2] Nalbant M., Altin A., Gökaya H. "The effect of cutting speed and cutting tool geometry on machinability properties of nikel-base Inconel 718 super alloys". Materials \& Design. 28 (2007): 1334-1338, https://doi.org/10.1016/j.matdes.2005.12.008.

[3] Szablewski P., Chwalczuk T. „Ocena morfologii powierzchni obrobionej stopu Inconel 718 po toczeniu wzdłużnym". Zeszyty Naukowe Politechniki Rzeszowskiej, 295, Mechanika 89, RUTMech. XXXIV, 89, 3/17 (lipiec-wrzesień 2017): 379-384, https://doi.org/10.7862/rm.2017.34.

[4] Bushlya V., Zhou J.M., Lenrick F., Avdovic P., Stål J.-E. "Characterization of White Layer Generated when Turning Aged Inconel 718". $1^{\text {st }}$ CIRP Conference on Surface Integrity (CSI), Procedia Engineering 19, (2011): 60-66, https://doi.org/10.1016/j.proeng.2011.11.080.

[5] Bosheh S.S., Mativenga P.T. „White layer formation in hard turning of $\mathrm{H} 13$ tool steel at high cutting speeds using CBN tooling". International Journal of Machine Tools \& Manufacture. 46 (2006): 225-233, https://doi.org/10.1016/j.ijmachtools.2005.04.009.

[6] Sharman A.R.C., Hughes J.I., Ridgway K. "The effect of tool nose radius on surface integrity and residual stresses when turning Inconel 718 ${ }^{\mathrm{TM}}$ ". Journal of Materials Processing Technology. 216 (2015): 123-132, https://doi.org/10.1016/j.jmatprotec.2014.09.002.

[7] Jafarian F., Amirabadi H., Sadri J. „Experimental measurement and optimization of tensile residual stress in turning process of Inconel 718 superalloy". Measurement. 63 (2015): 1-10. https://doi.org/10.1007/s00170-016-9737-3.

[8] Dudzinski D., Devillez A., Moufki A., Larrouqiere D., Verrouki V., Vigneau J. „A review of developments towards dry and high speed machining of Inconel 718 alloy". International Journal of Machine Tools \& Manufacture. 44, (2004): 439-456, https://doi.org/10.1007/s00170-016-9737-3.

[9] Mohsan A.U.H., Zhanqiang L., Padhy K.G. „A review on the progress towards improvement in surface integrity of Inconel 718". International Journal of Advanced Manufacturing Technology. 91, 1-4 (2017): https://doi.org/107-125, 10.1007/s00170-016-9737-3.

[10] Axinte D.A., Andrews P., Li W., Gindy N., Withers P.J. „Turning of advanced Ni based alloys obtained via powder metallurgy router". Annals of the CIRP. 55/1 (2006): 117-120, https://doi.org/10.1016/S00078506(07)60379-5. 